\title{
Habitat, microdistribution and conservation status of the enigmatic Bruijn's Brush-turkey Aepypodius bruijnii
}

IWEIN MAURO

\section{Summary}

The endemic brush-turkey of Waigeo Island in eastern Indonesia, Aepypodius bruijnii, is revealed to nest only on the island's previously ornithologically unexplored highest summits, along an ecological gradient above $620 \mathrm{~m}$ elevation where a structurally distinctive, windsheared and possibly locally edaphically controlled, stunted cloud-forest thrives on infertile substrates. The species is confirmed to breed at two locations only, and the known population totals 47 mound-owning males or 84 mature individuals. Its global population is estimated at 349 mound-owning males or 977 mature individuals, primarily confined to $60 \mathrm{~km}^{2}$ of cloudforest habitat spread over six locations, with $98 \%$ of the population restricted to just three locations in the eastern part of the island. Details are provided on the bird's altitudinal distribution, habitat preferences, spatio-temporal use of incubation sites, population densities, locations and incidental lowland records. Threats that impinge on the species are discussed in depth, and it is concluded that its current precautionary treatment as Vulnerable warrants upgrading to Endangered in accordance with the revised IUCN Red List categories and criteria. Habitat destruction as a consequence of wild fires and a recent logging epidemic is identified as the major factor threatening this unique brush-turkey's long-term survival.

\section{Introduction}

In spite of 22 historical ornithological expeditions and modern reconnaissance visits (Mauro 2004, 2005) and two rediscoveries (De Schauensee 1940; Heij and Post 2001), Bruijn's Brush-turkey Aepypodius bruijnii remained entirely unknown in the living world for more than 120 years between its formal description and its recent field discovery reported in detail by Mauro (2002, 2004, 2005). At one time it was even doubted whether the large Pleistocene island fragment of Waigeo (c. 3,100 $\mathrm{km}^{2}$; $\mathrm{O}^{\circ} \mathrm{I} 2^{\prime} \mathrm{S}, 130^{\circ} 45^{\prime} \mathrm{E}$; Figure $\mathrm{I}$ ) at the northern extremity of the Raja Ampat archipelago in Indonesian New Guinea genuinely was its terra typica (Peters 1934; De Schauensee 1940). Any comment on the species' conservation status remained tentative in the absence of biological information. It was initially classified as Endangered (Dekker and McGowan 1995; Stattersfield et al. 1998) chiefly on the principle of reasonable precaution, although was recently downgraded to Vulnerable (Dekker et al. 2000; BirdLife International 2001) as a result of more stringent evaluation criteria.

Bruijn's Brush-turkey belongs to the megapodes (Megapodiidae), a family renowned for its exceptional incubation strategy, exploiting environmental heat sources and exhibiting no parental care (overview in Jones et al. 1995). I previously 


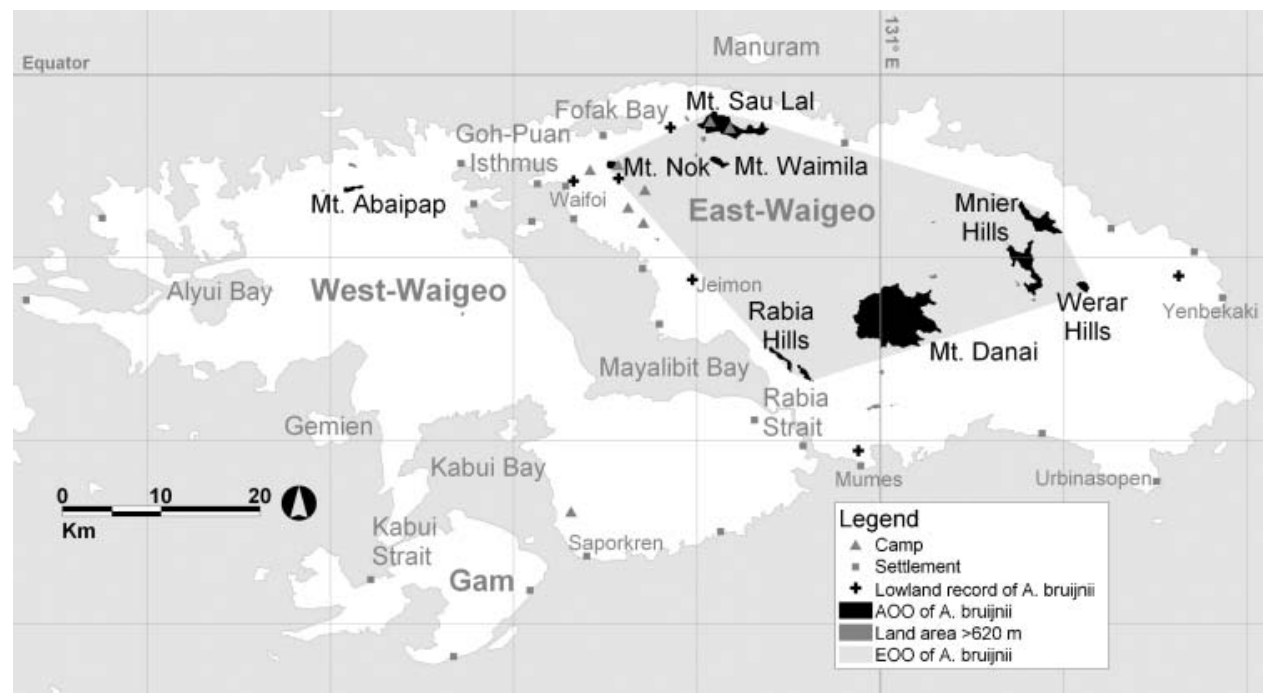

Figure 1. Locations of Bruijn's Brush-turkey Aepypodius bruijnii on Waigeo, with the distribution of land above $620 \mathrm{~m}$ elevation and the position of incidental lowland records.

confirmed that the species builds heaps of leaf litter and other organic material (henceforth called 'mounds'), in which the heat produced by microbial decomposition incubates the eggs (Mauro 2002, 2004, 2005). I also provided circumstantial evidence for its presumed male resource-defence polygyny and polyandry mating system (Mauro 2004, 2005), uniquely among the megapodes rooted within the closely allied New Guinean and Australian brush-turkey genera Aepypodius and Alectura. In the brush-turkeys, adult male territoriality is assumed to centre on the mound and vocal advertisement is restricted entirely to the mating season proper and may primarily be associated with sexual display on, or in the immediate vicinity of, the mound (Jones et al. 1995; Sinclair 2002; I. M. unpublished data). The number of reproductively mature males capable of permanently defending a mound is the single most relevant population unit for conservation assessment in a male resource-defending promiscuous megapode, given that exactly these males secure virtually all copulations, and monopolize the chance of successful progeny (see Jones 1990a, b).

Here, I assess this critical population parameter, and explore the conservation status and needs of this truly enigmatic taxon, founded on insights gained during multiple and prolonged field surveys of Waigeo's previously ornithologically unexplored summits.

\section{Methods}

During pilot surveys in April-May 2002 (Table 1, Figure I) I discovered Bruijn's Brush-turkey in the field on Mount Nok and gained insight into its vertical breeding distribution (Anonymous 2002a, b, Mauro 2002, 2004, 2005). This prompted follow-up fieldwork in October-December 2002 and May-June 2003 (Table 1, Figure I). I timed new fieldwork based on: (I) Information that Waigeo receives an annual rainfall of $1,500-2,000 \mathrm{~mm}$ (van Royen 1960), most of which falls in a 
Table 1. Survey effort at key study sites on Waigeo.

\begin{tabular}{|c|c|c|c|c|c|c|}
\hline Study site & $\begin{array}{l}\text { Camp } \\
\text { altitude } \\
\text { (m) }\end{array}$ & $\begin{array}{l}\text { Camp coordinates } \\
\text { (WGS '84) }\end{array}$ & Study period & $\begin{array}{l}\text { No. of } \\
\text { field } \\
\text { days }\end{array}$ & $\begin{array}{l}\text { Person-hour } \\
\text { search effort }\end{array}$ & $\begin{array}{l}\text { Altitude } \\
\text { covered } \\
\text { (m) }\end{array}$ \\
\hline $\begin{array}{l}\text { Saporkren } \\
\text { area }\end{array}$ & 140 & $\mathrm{~S} 0^{\circ} 26^{\prime} 16^{\prime \prime} \mathrm{E} 130^{\circ} 43^{\prime} 46^{\prime \prime}$ & $09-21.04 .02$ & 10 & 160 & $0-235$ \\
\hline $\begin{array}{l}\text { Waifoi coastal } \\
\text { forest }\end{array}$ & o & $\mathrm{S} 0^{\circ} 0^{\prime} 59^{\prime \prime} \mathrm{E} 130^{\circ} 42^{\prime} 51^{\prime \prime}$ & $\begin{array}{l}31.05-02.06 / \\
17-18.11 .02\end{array}$ & 5 & 200 & o-100 \\
\hline $\begin{array}{l}\text { Cempedak } \\
\text { Camp }\end{array}$ & 345 & $\mathrm{~S} 0^{\circ} 05^{\prime} 13^{\prime \prime} \mathrm{E} 130^{\circ} 44^{\prime} 12^{\prime \prime}$ & $29.04-12.05 .02$ & 14 & 560 & $280-665$ \\
\hline $\begin{array}{l}\text { Mount Nok } \\
\text { Base Camp }\end{array}$ & 730 & $\mathrm{~S} 0^{\circ} 04^{\prime} 57^{\prime \prime} \mathrm{E} 130^{\circ} 45^{\prime} 43^{\prime \prime}$ & $\begin{array}{l}14-28.05 / \\
05-16.11 .02\end{array}$ & 27 & 944 & $465-880$ \\
\hline $\begin{array}{l}\text { Mangkawan } \\
\text { Hills Camp }\end{array}$ & 140 & $\mathrm{~S} 0^{\circ} 06^{\prime} 18^{\prime \prime} \mathrm{E} 130^{\circ} 47^{\prime} 11^{\prime \prime}$ & $21-26.10 .02$ & 7 & 280 & $140-340$ \\
\hline $\begin{array}{l}\text { Waremag } \\
\text { River Camp }\end{array}$ & 30 & $\mathrm{~S} 0^{\circ} 07^{\prime} 16^{\prime \prime} \mathrm{E} 130^{\circ} 46^{\prime} 16^{\prime \prime}$ & $\begin{array}{l}27-28.10 / \\
04.11 .02\end{array}$ & 3 & 120 & $30-60$ \\
\hline $\begin{array}{l}\text { Mobit Hills } \\
\text { Camp }\end{array}$ & 285 & $\mathrm{~S} 0^{\circ} 08^{\prime} 05^{\prime \prime} \mathrm{E} 130^{\circ} 47^{\prime} 06^{\prime \prime}$ & $29.10-03.11 .02$ & 6 & 240 & $285-560$ \\
\hline $\begin{array}{l}\text { Mount Sau } \\
\text { Lal Camp }\end{array}$ & 780 & $\mathrm{~S} 0^{\circ} \mathrm{O}^{\prime} 34^{\prime \prime} \mathrm{E} 130^{\circ} 5 \mathrm{O}^{\prime} 45^{\prime \prime}$ & $\begin{array}{l}20.11-16.12 .02 / \\
14-21.05 .03\end{array}$ & 35 & 1,336 & $500-970$ \\
\hline $\begin{array}{l}\text { Wekabau } \\
\text { Ridge Camp }\end{array}$ & 780 & $\mathrm{~S} 0^{\circ} \mathrm{O} 2^{\prime} 55^{\prime \prime} \mathrm{E} 130^{\circ} 51^{\prime} 49^{\prime \prime}$ & $22.05 .03-13.06 .03$ & 23 & 736 & $500-930$ \\
\hline
\end{tabular}

distinctive wet season from December through to May (local information). (2) The finding that elsewhere in seasonally humid environments the onset of breeding for mound-building megapodes is defined by local precipitation regimes (Jones et al. 1995). (3) My own observation that incubation was in progress on Mount Nok in mid-May 2002 (Mauro 2002, 2004, 2005). Severe drought conditions, exacerbated by the El Niño warm episode of an ENSO weather disturbance, however, afflicted the region during 14 consecutive months spanning June 2002 to July 2003. The vegetation of the entire Raja Ampat district showed signs of drought stress by NovemberDecember 2002 (Takeuchi 2003), and I noted rainfall only on seven out of 87 field days during this period.

Reproductive and vocal activity in Bruijn's Brush-turkey was not forthcoming, hence I relied exclusively on qualitative mapping of its mounds to assess population status. Assisted by a team of local hunters, I performed a systematic and exhaustive search in the Mobit and Mangkawan Hills, on Mounts Nok and Sau Lal (Table 1, Figure 1). Except for the western slopes of Mount Sau Lal, where post-fire successional low-stature scrub and pioneering woodland occurred up to an elevation of $820 \mathrm{~m}$ locally, the predominant vegetation everywhere was multi-storied, closed-canopy primary forest, details of which will appear elsewhere. In total, inclusive of the pilot surveys, I searched for 4,576 person-hours; initially within every altitudinal belt, later confined mainly to the increasingly tested and confirmed altitudinal breeding distribution. I spot-mapped each mound using GPS and a barometric altimeter, and assigned it to one of four distinctive phases through which the mounds of this species normally pass: construction phase, active phase, collapsed phase and spread-out phase (Mauro 2004, 2005). By repeating this procedure over disjunct survey periods, I obtained snapshots that provide insight into spatio-temporal distribution and utilization of incubation sites. I also described the main physical characteristics of mound sites, with special reference to distances from ridge tops and suspected 
permanent and temporary water sources, gradient, and aspect of the site. Given that Bruijn's Brush-turkey and the only other megapode on the island, Dusky Scrubfowl Megapodius freycinet, breed in complete vertical parapatry (Mauro 2004; see below), the issue of assigning mounds to species is not under discussion here. I restrict the term 'active' mound to the period of thermal stability of the mound, recognizable on account of its characteristic plateau shape (cf. maintenance phase in Jones 1988b; active phase in Mauro 2004, 2005), during which incubation of eggs may take place. I further considered mounds to be 'tended' whenever there was evidence of them being manipulated, from the spreading out of the compacting material of a cooled mound onward.

The lowest altitude at which I recorded a mound of Bruijn's Brush-turkey was 620 $\mathrm{m}$. Adopting this as an altitudinal cut-off, I delineated in a study area (henceforth SA) for Mounts Nok and Sau Lal, the external boundary of breeding habitat realistically suitable to the species through exclusion of geomorphologically unsuited terrain by means of combining GPS-waypoints, sketch-mapping and panoramic photography. Within the Mount Sau Lal SA I also mapped broad habitat types. I applied nearest neighbour and Delaunay/Dirichlet tessellation connection schemes to describe and analyse spatio-temporal distribution of incubation sites within the Mount Sau Lal SA. Quoted distances are spherical (geodesic) not considering slope.

I used the unedited NGA-NASA SRTM-3 three arc-second resolution digital elevation model to assess distribution and extent of land above $620 \mathrm{~m}$ elevation on Waigeo, and estimate the species' breeding range and total world population. However, SRTM-3-derived 620 m contour surfaces for Mounts Nok and Sau Lal exceeded their corresponding manually delineated SAs by factors of 2.05 and 1.47 respectively, and application of SA densities to SRTM-3 surfaces would thus return grotesque population overestimates. Therefore, I applied correction factors $\mathrm{C}_{<_{2} \mathrm{~km}^{2}}=0.49$ to small relicts $<_{2} \mathrm{~km}^{2}$ and $\mathrm{C}_{>_{2} \mathrm{~km}^{2}}=0.68$ for SRTM-3 surfaces $>_{2} \mathrm{~km}^{2}$ based on the proportional SA/SRTM-3 discrepancy for the relict Mount Nok and the sizeable Mount Sau Lal, respectively. I calculated a single most parsimonious population estimate applying the observed mound-territory $/ \mathrm{km}^{2}$ density for Mount Nok $\mathrm{D}_{<_{2} \mathrm{~km}^{2}}$ $=4.01$ to SRTM-3 relicts $<2 \mathrm{~km}^{2}$, and the mean for primary forest on Mount Sau Lal $\mathrm{D}_{>_{2} \mathrm{~km}^{2}}=9.19$ to surfaces $>_{2} \mathrm{~km}^{2}$. I removed from further analysis 20 SRTM-3 620 $\mathrm{m}$ relicts averaging $0.09 \mathrm{~km}^{2}\left( \pm 0.1 ; 0.003-0.39 \mathrm{~km}^{2} ; n=20\right)$ and totalling $1.78 \mathrm{~km}^{2}$ that were too tiny to hold a single territory at the applicable $\mathrm{D}_{<_{2} \mathrm{~km}^{2}}$ density. Based on the mean impact of the most serious threatening process (see below), I further considered separate $620 \mathrm{~m}$ contours $<3.5 \mathrm{~km}$ apart and interconnected through a ridge not descending below $450 \mathrm{~m}$ as a single 'location' in the sense of the IUCN Red List categories and criteria (IUCN 2001), and throughout use the term only in this specific sense. Finally, I estimated extent of occurrence (EOO) by minimum convex polygon (MCP) around locations, and area of occupancy (AOO) by $4 \mathrm{~km}^{2}$-cell grid-mapping of known records excluding cases of vagrancy (IUCN 2001, 2003).

\section{Results}

\section{Altitudinal distribution and habitat preferences}

I found incubation sites of Bruijn's Brush-turkey only on Mounts Nok $(n=3)$ and Sau Lal $(n=75)$ at an average altitude of $769 \mathrm{~m}( \pm 92.8 ; 620-930 \mathrm{~m} ; n=78)$, along an 
ecological gradient above $620 \mathrm{~m}$ elevation, where a structurally distinctive, windsheared and possibly locally edaphically controlled, stunted cloud-forest grows on infertile ultramafic rocks. Such 'Kruppelholz' formations typically were thin-stemmed, rarely exceeding $20 \mathrm{~cm}$ diameter at breast height, grew $c .7-12 \mathrm{~m}$ tall, with occasional emergents in sheltered valleys up to c. $18 \mathrm{~m}$ (contra Moeliker and Heij 2002, who reported trees c. $40 \mathrm{~m}$ in height from the summit area of Mount Nok), and featured gnarled trunks and branches heavily draped in epiphytic moss and ferns, and a dense understorey of seedlings, saplings and palms (particularly Pandanus). On the relict Mount Nok (Table 2) all three incubation sites were located at 705-730 m within a very restricted area around the summit that is shrouded in clouds during parts of most days. I did not record the species below $620 \mathrm{~m}$ in spite of having devoted in excess of 1,940 person-hours or $42.4 \%$ of search effort there. Moreover, I noted merely three credible testimonies of brush-turkeys, each involving solitary, apparently female types, having been hunted within recent living memory from low-lying sectors of Mounts Nok and Sau Lal exploited by humans on a regular basis. One was snared close to the village grounds of Waifoi near sea level c. 1986, another captured by dogs along the Apiap River at c. 30 m near O ${ }^{\circ}{ }^{\prime}{ }_{5} 6^{\prime \prime} \mathrm{S}, 130^{\circ} 48^{\prime} 34^{\prime \prime} \mathrm{E}$ in the early 1990 , and the last individual, also taken by dogs in the mid-1990s, was along a small tributary of the Wai Paley River near $0^{\circ} 5^{\prime} 43^{\prime \prime} \mathrm{S}, 130^{\circ} 45^{\prime} 44^{\prime \prime} \mathrm{E}$ at $c$. $110 \mathrm{~m}$ in the general area locally known as Katotara (Figure 1 ).

Dusky Scrubfowl was found to occur principally in flat alluvial lowland forests along the broader river valleys between sea level and c. I00 $\mathrm{m}$. Here its huge mounds

Table 2. Locations of Bruijn's Brush-turkey Aepypodius bruijnii on Waigeo ranked in declining order of importance.

\begin{tabular}{|c|c|c|c|c|c|}
\hline $\begin{array}{l}\text { Location sensu } \\
\text { IUCN (2001) }\end{array}$ & & $\begin{array}{l}\text { Summit } \\
\text { altitude (m) }\end{array}$ & $\begin{array}{l}\text { Summit } \\
\text { coordinates } \\
(\text { WGS '84) }\end{array}$ & $\begin{array}{l}\text { SRTM-3 } \\
620 \text { m contour } \\
\text { area }\left(\mathrm{km}^{2}\right)\end{array}$ & $\begin{array}{l}\text { Inferred no. of } \\
\text { mound-owning } \\
\text { males }^{a}\end{array}$ \\
\hline Mount Danai & & 950 & $\begin{array}{l}\mathrm{S} 00^{\circ} 12^{\prime} 08^{\prime \prime} \\
\mathrm{E} 131^{\circ} 00^{\prime} 53^{\prime \prime}\end{array}$ & 36.19 & 226.4 \\
\hline \multirow[t]{3}{*}{$\begin{array}{l}\text { Mnier-Werar } \\
\text { Hills }\end{array}$} & Mnier Hills & 870 & $\begin{array}{l}\mathrm{S} 00^{\circ} 10^{\prime} 04^{\prime \prime} \\
\mathrm{E} 131^{\circ} 07^{\prime} 54^{\prime \prime}\end{array}$ & 10.717 & 67 \\
\hline & Werar Hills & 760 & $\begin{array}{l}\mathrm{S} 00^{\circ} 11^{\prime} 31^{\prime \prime} \\
\mathrm{E} 131^{\circ} 11^{\prime} 07^{\prime \prime}\end{array}$ & 0.823 & 1.6 \\
\hline & Subtotal & & & 11.539 & 68.6 \\
\hline \multirow[t]{3}{*}{$\begin{array}{l}\text { Mounts Sau } \\
\text { Lal-Waimila }\end{array}$} & Mount Sau Lal & 970 & $\begin{array}{l}\mathrm{S} 00^{\circ} \mathrm{O} 2^{\prime} 29^{\prime \prime} \\
\mathrm{E} 130^{\circ} 51^{\prime} 05^{\prime \prime}\end{array}$ & 8.038 & $45^{\mathrm{b}}$ \\
\hline & Mount Waimila & 710 & $\begin{array}{l}\mathrm{S} 00^{\circ} \mathrm{O} 2^{\prime} 29^{\prime \prime} \\
\mathrm{E} 130^{\circ} 51^{\prime} 05^{\prime \prime}\end{array}$ & 0.974 & 1.9 \\
\hline & Subtotal & & & 9.012 & 46.9 \\
\hline Rabia Hills & & 720 & $\begin{array}{l}\mathrm{S} 00^{\circ} 15^{\prime} 45^{\prime \prime} \\
\mathrm{E} 130^{\circ} 55^{\prime} 04^{\prime \prime}\end{array}$ & 1.852 & 3.6 \\
\hline Mount Nok & & 880 & $\begin{array}{l}\mathrm{S} 00^{\circ} 04^{\prime} 54^{\prime \prime} \\
\mathrm{E} 130^{\circ} 45^{\prime} 17^{\prime \prime}\end{array}$ & 0.864 & $2^{b}$ \\
\hline Mount Abaipap & & 700 & $\begin{array}{l}\mathrm{S} 00^{\circ} 06^{\prime} 13^{\prime \prime} \\
\mathrm{E} 130^{\circ} 30^{\prime} 55^{\prime \prime}\end{array}$ & 0.676 & 1.3 \\
\hline Total & & & & 60.135 & 348.8 \\
\hline
\end{tabular}

${ }^{\mathrm{a}}$ Correction factor $\mathrm{C}_{<_{2} \mathrm{~km}^{2}}=0.488$ and density factor $\mathrm{D}_{<_{2} \mathrm{~km}^{2}}=4.01$ for small relicts $<_{2} \mathrm{~km}^{2} ; \mathrm{C}_{>_{2}} \mathrm{~km}^{2}=$ o.681 and $\mathrm{D}_{>_{2} \mathrm{~km}^{2}}=9.19$ for SRTM-3 $620 \mathrm{~m}$ surfaces $>_{2} \mathrm{~km}^{2}$ (see Methods).

${ }^{\mathrm{b}}$ For Mounts Sau Lal and Nok observed values are presented. 
typically were being maintained communally. Once beyond the foothill boundary proper, Megapodius incubation sites were confined to patchily distributed relatively extensive expanses of flat or only slightly undulating terrain, and were being tended by solitary territorial pairs (Mauro 2004, 2005). I found such isolated incubation sites locally at $230 \mathrm{~m}$ in limestone karst country in the Saporkren area, at $260 \mathrm{~m}$ in hill forest on ultrabasics along the western spine of Mount Nok and at a maximum elevation of $285 \mathrm{~m}$ in limestone karst country in the Mobit Hills (Table 1, Figure 1 ). In November 2002 I observed silent, solitary individuals at $465 \mathrm{~m}, 625 \mathrm{~m}$ and $730 \mathrm{~m}$ on Mount Nok.

I conclude that the two species breed in complete vertical parapatry, separated by an altitudinal gap exceeding $300 \mathrm{~m}$, set against a maximum elevation of $970 \mathrm{~m}$ available for the island.

Adult male brush-turkeys selected relatively steep slopes, sloping on average $24.3 \%$ ( $\pm 13.6 ; 0-60 \% ; n=70$ ), to establish incubation sites. The spatial distribution of incubation sites was overwhelmingly concentrated along the main crests and buttressed ridgetops, harbouring $89 \%$ of cases $(n=69)$ within the immediate vicinity of the apices and supporting flanks. The remaining nine were located within valleys near permanent water-holes in dry stream beds. Of 71 mounds, 45 (63\%) were on east- to south-facing slopes ( 18 faced E, 16 faced S, 11 faced SE, 8 faced N, 7 faced NE, 6 faced SW and 5 faced W). Of 78 mounds, 61 (78\%) were located in multi-layered primary forest with a closed canopy generally comprised of multiple dense, broadleaf crowns $c$. $10-18 \mathrm{~m}$ in height. Eleven (14\%) were within multi-storied, closed-canopy forest but directly below individual, often emergent conifers $c .9-15 \mathrm{~m}$ tall, featuring a comparatively open crown. Four $(5 \%)$ were in what appeared to be genuinely edaphically controlled dwarfish primary formations, typically virtually unlayered and densely stocked with $c$. 5-7 $\mathrm{m}$ thin-stemmed, dead-straight tree-poles. Finally, the remaining two $(3 \%)$ stood in low-stature $<_{5} \mathrm{~m}$ tall, generally open, completely unlayered secondary, pioneering woodland, recovering from wild fires in 1982-1983. In each of the latter three distinctive environmental circumstances, totalling $22 \%$ of cases $(n=17)$, solar radiation on the mounds in question was high. Whereas secondary, pioneering woodland comprised $18 \%$ of the Mount Sau Lal SA, only two mounds $(3 \%)$, were located within such woodland.

\section{Spatio-temporal use of incubation sites and population densities}

Average nearest neighbour distance for mounds synchronically tended on Mount Sau Lal was $204 \mathrm{~m}( \pm 47.3$; 141.7-346.7 $\mathrm{m} ; n=44)$. The two concurrently active mounds on Mount Nok were $399 \mathrm{~m}$ distant. Average population density at the Mount Sau Lal $\mathrm{SA}$ was estimated to be 8.2 mound-territories $/ \mathrm{km}^{2}$. However, density varied considerably across broad habitat types: from 2 mound-territories $/ \mathrm{km}^{2}$ in post-fire successional woodland, over 8 in edaphically controlled, pole-stemmed primary tracts, finally to 10.4 in multi-layered, closed-canopy primary forest. Mean density for primary formations thus was 9.2 mound-territories $/ \mathrm{km}^{2}\left(=\mathrm{D}_{>_{2}} \mathrm{~km}^{2}\right.$; see Methods, Table 2). Tentative delineation of mound-territories for the Mount Sau Lal SA applying Delaunay/Dirichlet tessellation of points representing simultaneously tended mounds (Figure 2) yields a mean mound-territory area of $0.08 \mathrm{~km}^{2}$ ( \pm 0.04 ; $0.04-0.22 \mathrm{~km}^{2} ; n=14$ ) for interlocked points and $0.14 \mathrm{~km}^{2}$ ( $\pm 0.1 ; 0.04-0.53 \mathrm{~km}^{2}$; $n=31$ ) for outlying spots. For the relict Mount Nok SA mean territory was $0.25 \mathrm{~km}^{2}$ 


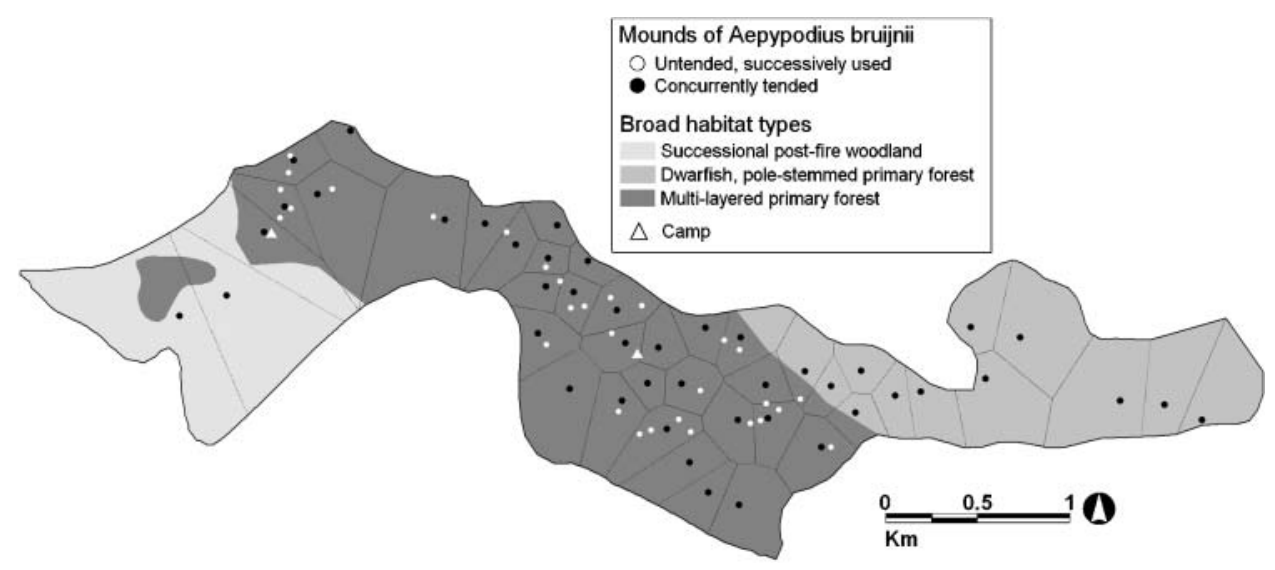

Figure 2. Spatio-temporal distribution of mounds of Bruijn's Brush-turkey Aepypodius bruijnii at the Mount Sau Lal study area: black dots represent concurrently tended mounds constituting the centroid of the Delaunay/Dirichlet tessellation arbitrarily defining each territory; white dots are locations of successively used, untended mounds.

$(n=2)$, i.e. a population density of 4 mound-territories $/ \mathrm{km}^{2}\left(=\mathrm{D}_{<_{2}} \mathrm{~km}^{2}\right.$; see Methods, Table 2).

In $57.8 \%(n=26)$ of the 45 delineated mound-territories above, only a single incubation site was found, i.e. the mound constituting the centroid of the tessellation delineating each territory. Respectively two, three, four and five successively used incubation sites were found in $27 \%(n=12), 9 \%(n=4), 4 \%(n=2)$ and $2 \%(n=1)$ of cases. Mean distances between up to four disused incubation sites within a territory and the centroid tended mound that defines it, comprised $82.5 \mathrm{~m}$ ( \pm 30.1 ; 31.8-153.2 $\mathrm{m} ; n=30$ ). Comparison of the status of 28 incubation sites that could be followed over both survey periods yields the following: ( 1 ) Of 24 that were tended in late 2002, 15 or $63 \%$ showed evidence of an intermittent abortive start of renovation and of ongoing manipulation in mid-2003. (2) Nine mounds or $38 \%$ showed no further evidence of manipulation. (3) Only one of these had been abandoned in favour of a novel half-finished construction $36 \mathrm{~m}$ away.

\section{Core breeding zones and global population}

Cloud-forest covers $61.9 \mathrm{~km}^{2}$ or $2 \%$ of Waigeo's land area. Excluding the $1.78 \mathrm{~km}^{2}$ scattered over 20 relicts too tiny to support even a single territory (see Methods), it is estimated that the breeding habitat of Bruijn's Brush-turkey comprises just $60.1 \mathrm{~km}^{2}$ or $1.9 \%$ of the island's area. Based on habitat extent and observed mound-territory densities a global population of 349 sexually mature mound-owning males is estimated (Table 2).

Three mountain systems in the eastern sector of Waigeo together contain $94 \%$ of breeding habitat and $98 \%$ of the total inferred world population of Bruijn's Brushturkey (Table 2, Figure 1). Mount Danai alone contains $60 \%$ of the breeding habitat and $65 \%$ of the total population. The Mnier-Werar Hills contain $19 \%$ of the habitat and $20 \%$ of the population, and Mounts Sau Lal-Waimila $15 \%$ of habitat and $13 \%$ of the population. The remaining $5.6 \%$ of the breeding habitat and $2 \%$ of the inferred 
global population are contained within three locations ranging between 0.68 and $1.85 \mathrm{~km}^{2}$.

\section{Discussion}

\section{Altitudinal distribution and habitat preferences}

The rarity of Bruijn's Brush-turkey has been linked to potential competitive exclusion by the ecologically similar Dusky Scrubfowl (Dekker and Argeloo 1993, BirdLife International 2001), considered a more recent arrival on Waigeo. However, my work reveals that the two breed in complete vertical parapatry, and a relatively wide phylogenetic gap within Dusky Scrubfowl (Birks and Edwards 2002) suggests that Megapodius also has an ancient history on the island and that the disjunct breeding zones the two species maintain are the result of a long-term and stable evolutionary status quo.

I did not record Bruijn's Brush-turkey below $620 \mathrm{~m}$ in spite of having invested in excess of 1,940 person-hours there. Moreover, a conservative estimate of previous scientific ornithological field effort below $500 \mathrm{~m}$ on Waigeo easily arrives at 23,300 person-hours (Mauro 2004) with only a single specimen record for the species (De Schauensee 1940). However, two permanent records now exist for the true lowlands of Waigeo, in addition to three credible local testimonies I report on above. The preserved head and gnawed bones acquired by the Natuurmuseum Rotterdam (NMR \# 998901605) belonged to a female taken in late November 2000 by local hunters within ultrabasic scrub and woodland at $150 \mathrm{~m}$ along a tributary of the Werar River c. $4 \mathrm{~km}$ inland from Yenbekaki (Heij and Post 2001; Figure 1). The first live specimen (NMR \# 9989-01606) was also a female, with well-developed ovary; it was snared in mid-July 2002 within internally degraded mature foothill forest at $c .80 \mathrm{~m}$ in limestone country c. $3 \mathrm{~km}$ due east of Mumes (Moeliker et al. 2003; Figure 1). In addition, the 1938 female (ANSP \# 140581) from Jeimon (De Schauensee 1940) certainly originated from outside the species' breeding habitat and was definitely collected below $640 \mathrm{~m}$ (Mauro 2004; Figure 1).

Four respondents who had hunted the species, associated its occurrence with prolonged periods of drought, and the circumstances of the specimen from Mumes are consistent with a presumed drought etiology. My work revealed that adult moundtending males endured extreme drought conditions on territory, whereas female types appeared to have completely vacated optimum cloud-forest habitat (Mauro 2004, 2005), and all lowland records to date involve female-type individuals. However, the species ranks as technically undetectable when dispersed in small numbers across vast lowlands, hence the possibility looms that such apparent altitudinal shifting of female types extends far beyond the casual disturbance-response, and obscures juvenile dispersal and/or genetically strategic interchange of adults between isolated breeding habitats. As a matter of reasonable precaution, any in situ conservation initiative for the species should therefore soundly consider this potential temporal dependency upon lowlands of at least a subset of the population.

I conclude that the best available evidence suggests lowland occurrences are incidental (contra Moeliker 2002a, b), and recommend these be treated as cases of vagrancy with regard to applying criterion B of the IUCN Red List criteria (IUCN 2001; see below). All traceable positions of lowland records were on average only 
$5.9 \mathrm{~km}( \pm 3.88 ; 1.1-10.3 \mathrm{~km} ; n=6)$ distant from the nearest known or inferred breeding habitat and lie east of Mayalibit Bay.

With $89 \%$ of cases concentrated along the main crests and buttressed ridgetops, it seems plausible that Bruijn's Brush-turkey primarily selects incubation sites on the basis of an optimal projection along declivities of male advertising calls (see also Sinclair 2002). That east- to south-facing slopes appeared to be favoured, may further be related to the fact that these receive sunlight during presumed morning sexual display, though the amount of suitable land on west- and north-facing slopes was also disproportionately restricted. Characteristics related to provisioning of organic material and protection of the mound from desiccation, as advanced in other megapode studies (Jones 1988a, Sinclair 2002), probably determined $78 \%$ of disclosed incubation sites that promoted a stable microhabitat. The likelihood that a combination of solar and microbial heat nurtures incubation in the remaining $22 \%$ of cases (cf. Palmer et al. 2000), constitutes a confounding factor with respect to site selection. Finally, more than 20 years after the last fire event on Mount Sau Lal, the species' population density in areas of post-fire succession there was still 4.5 times lower than in adjacent primary tracts.

\section{Spatio-temporal use of incubation sites and population densities}

Sinclair (2001) demonstrated disadvantages of mound renovation over novel construction in terms of thermal conductivity. However, I consider it impossible that additional disused mounds could have been systematically overlooked in $58 \%$ of delineated mound-territories at the Mount Sau Lal SA that held only a single incubation site. Therefore, I advance recurrent utilization of these sites over successive breeding seasons as the most parsimonious explanation. A comparison of the status of 28 incubation sites that could be followed over both survey periods is consistent with such recurrent use over consecutive years. However, out of 24 mounds tended in late 2002, there were only 10 cases where successful incubation during the previous breeding season could be positively inferred either from the collapsed state of a mound or the fact that it constituted the centroid of the territory it defines. Conversely, occurrence of up to five successively used incubation sites in the remaining $42 \%$ of mound-territories is in agreement with rotational usage of incubation sites over successive breeding seasons as described by Jones (1988a, b, 1990a, b) for Alectura.

On present evidence territorial adult males ordinarily tend a single mound only during a breeding season. However, since construction of a second mound may be expected to commence only after the first reaches thermal stability (Jones 1988b), and this particular condition was evidently being impeded by ongoing drought conditions during this study (see Methods), synchronous attendance of two mounds by the same territorial male may have gone largely unnoticed. Nevertheless, whilst for $42 \%$ of territories the possibility of concurrent utilization cannot be ruled out, such an occurrence due to the extreme density of the favoured breeding habitat was likely in only three cases where presumed doublets were separated by 32,36 and $42 \mathrm{~m}$ respectively, and showed evidence of recent manipulation.

Little comparable published information exists on population densities in megapodes derived from qualitative mapping of mounds. However, with an observed 4-8 moundterritories $/ \mathrm{km}^{2}$, Bruijn's Brush-turkey probably ranks as a low-density species. In 
comparison, Alectura in the wild occurs at densities of 22.2 mound-territories $/ \mathrm{km}^{2}$ (Marchant and Higgins 1993), an order of magnitude 2.4-5.5 times greater.

\section{Core breeding zones and global population}

The lack of information on sex-ratio and turnover rate of breeding individuals in the species dictates that numerical quantification of its total reproductively mature population (IUCN 2001) can only be achieved through inference by analogy with closely allied taxa. In three studies of Alectura (Jones 199ob; D. N. Jones in litt., August 2004), soliciting sexually mature females outnumbered mound-owning males by a factor of 1.8 on average $( \pm 0.05 ; 1.75-1.85 ; n=3)$. If this figure is applied to the estimated number of mound-owning males in Bruijn's Brush-turkey (Table 2), a global population of 977 mature individuals is estimated. This score does not include an unestimatable pool of non-breeders, thought to be mostly males (Jones 1987).

Of six locations identified (Table 2, Figure 1), Bruijn's Brush-turkey is currently confirmed to breed on Mounts Sau Lal and Nok only, and the known population totals 47 mound-owning males or 84 mature individuals. A recent botanical survey that reached elevations up to $700 \mathrm{~m}$ on Mount Danai, established that forests remain in pristine condition there (C. Webb in litt., June 2005). In contrast, sizeable tracts in the Mnier Hills appeared to be covered with low-stature scrub and anthropogenic grasslands (Mauro 2004), and hence the population estimate for the Mnier-Werar Hills is almost certainly too high. Additional work may well bring to light that a number of the selected relicts do not support a breeding population after all. This possibility seems particularly plausible for Mount Abaipap west of Mayalibit Bay, given its comparatively higher degree of isolation from viable recruitment sources and the complete lack of reliable records for the species this side of the bay (but see Diamond 1986). The critically low population ceilings of all relicts moreover suggest an imminent risk of at least temporary extirpation.

I conclude that only the three principal locations, together containing $98 \%$ of the world population, are meaningful for the long-term survival of Bruijn's Brush-turkey, and until a population is proven extant west of Mayalibit Bay, recommend querying its occurrence there. This reduces the species' EOO to $1,734 \mathrm{~km}^{2}$ if the entire eastern part of the island up to the Goh-Puan bottleneck is considered. An MCP around the five locations that side of the bay yields an EOO of $751 \mathrm{~km}^{2}$. Present AOO tallies six $4 \mathrm{~km}^{2}$ cells or $24 \mathrm{~km}^{2}$. Moreover, even if future fieldwork should prove all locations within its EOO to be fully saturated at the IUCN $4 \mathrm{~km}^{2}$ grid cell reference scale, AOO still could not exceed $192 \mathrm{~km}^{2}$. Finally, I recommend that Bruijn's Brush-turkey, pending further field investigation on neighbouring Batanta Island where there is a tentative report (Diamond 1986), continues to be treated as endemic to Waigeo, as has been done by practically all recent authors (see e.g. Jones et al. 1995, Dekker et al. 2000, BirdLife International 2001).

\section{Conservation and the future of Bruijn's Brush-turkey}

Waigeo consists predominantly of limestone and ultrabasics, infertile substrates that are known to delay recovery of vegetation following environmental perturbation (overview in Proctor 2003). I identified habitat destruction as a result of wild fires as the most serious threatening process for Bruijn's Brush-turkey. Four traceable fire 
paths from the past 25 years averaged $64.8 \mathrm{~km}^{2}\left( \pm 46.4 ; 2.5-200 \mathrm{~km}^{2} ; n=4\right)$, together affecting c. $259 \mathrm{~km}^{2}$ or $8.4 \%$ of the island's area (Mauro 2004). These known fire events acted over disproportionately large surfaces when compared with the size of individual locations of the species (Table 2). Fires are directly responsible for severe internal degradation and partial obliteration of $18 \%$ of cloud-forest on Mount Sau Lal together with a presently unquantifiable yet significant portion of the Mnier Hills, and probably irretrievably degraded hundreds of square kilometres of low-lying forested areas, including corridors between locations. The impact of fire must also be assessed against the backdrop that the predominant scrub vegetation over ultramafic outcrops on Waigeo, long interpreted as an edaphic climax, is now considered to represent an early stage in a successional sequence induced by fire (Takeuchi 2003, see also Proctor 2003). Finally, three out of four wild fires occurred during the El Niño-induced drought event of 1982-1983, but interviews indicated that most fires on the island are started deliberately, and the use of fire has certainly increased significantly in the wake of logging operations.

In the accessible lowlands of Waigeo, forest is being lost at an extremely alarming pace due to recent illegal logging. About $14 \%$ of the West Waigeo Nature Reserve was already affected in 2000 (Anonymous 2000), and evidence is mounting that most of the accessible tracts within the reserve have by now been severely degraded by the usual interplay of logging, road building, and the widespread subsequent use of fire as a cover-up. While timber extraction proper will probably only affect low-lying areas in the short term, the preservation of lowland forest corridors linking breeding habitats of Bruijn's Brush-turkey is imperative in view of a potential temporal dependency upon lowlands of at least a subset of the population.

My work suggests that human predation, contrary to previous speculations (e.g. Dekker and McGowan 1995, Moeliker 2002a, b), is currently a negligible threat to the population, and that introduced mammalian predators may be a more serious cause for concern. Runaway dogs are certainly a problem locally (Mauro 2002, 2004) and constitute a hazard to Bruijn's Brush-turkey in view of its reluctance to flush (Mauro 2004, 2005). In addition, the prehistorically introduced wild boar Sus scrofa and the native monitor lizard Varanus indicus are suspected nest predators (Mauro 2004).

I propose that the species, currently treated as Vulnerable (BirdLife International 2001), be upgraded to Endangered (EN) based on criteria BI+2ab(ii, iii, v) (IUCN 2001). Bruijn's Brush-turkey is almost certainly confined to an area of $1,734 \mathrm{~km}^{2}$ in the eastern half of Waigeo and its EOO as delineated by MCP comprising all locations there amounts to $751 \mathrm{~km}^{2}\left(<5,000 \mathrm{~km}^{2}\right.$; criterion $\left.\mathrm{BI}\right)$. The species' AOO now stands at $24 \mathrm{~km}^{2}$ and even if all locations within its EOO eventually should prove to be fully saturated at the IUCN $4 \mathrm{~km}^{2}$ grid cell reference scale, still could not exceed $192 \mathrm{~km}^{2}$ $\left(<500 \mathrm{~km}^{2}\right.$; criterion $\left.\mathrm{B} 2\right)$. Viable populations that are safe from genetic stochasticity exist at only three locations $(<5$ locations; qualifier a). Fires severely degraded and partially obliterated $18 \%$ of the Mount Sau Lal SA together with a significant portion of the Mnier Hills, and quite possibly irretrievably degraded hundreds of square kilometres of low-lying forested areas including corridors between disjunct breeding zones (qualifier b(ii, iii)). A continuing decline in number of mature individuals is inferred from the species' observed constrained population density in post-fire successional regrowth on Mount Sau Lal (qualifier b(v)).

The entire world population of Bruijn's Brush-turkey is believed to occur east of Mayalibit Bay and this has far-reaching implications for conservation planning and 
prioritization on Waigeo. The East Waigeo Nature Reserve covers 1,195 $\mathrm{km}^{2}$ or $69 \%$ of the island's eastern half (Mauro 2004). However, almost a decade since its formal establishment, precise boundaries still need to be defined and it is unknown at present how well the reserve maps onto the $751 \mathrm{~km}^{2}$ MCP delineating the species' EOO (Figure 1, Table 2). An effort to harmonize borders is especially relevant at this time as a development master plan for the Raja Ampat regency is currently being drawn up. More generally, based on the principle of representation, in terms of both species diversity and habitats, the region east of Mayalibit Bay must now immediately be upgraded as the key area for terrestrial conservation on Waigeo. In addition, I recommend that: (I) an island-wide awareness campaign is set up to prevent future wild fires; (2) 'parforce' pig-hunting and snaring be restricted to designated sectors near habitation and subsistence areas; and (3) the species' core locations be declared strictly 'no hunting areas' and accessed for scientific monitoring only (Mauro 2004).

Finally, from a conservation point of view five research priorities emerge: (I) Establish with absolute certainty that populations of Bruijn's Brush-turkey indeed are present at both inferred principal locations (Mount Danai and the Mnier-Werar Hills) and the remaining hitherto unsurveyed ridges and peaks identified in this study. (2) Establish beyond reasonable doubt whether the species is genuinely absent from Batanta. (3) Study nesting-site philopatry and the extent of gene flow across locations, preferably using a non-invasive molecular technique. (4) Investigate the impact of ENSO-induced drought events on the species' reproductive success. (5) Study the impact of alien mammalian predators on the island.

\section{Acknowledgements}

Fieldwork was funded through two small grants from the Van Tienhoven Foundation for International Nature Protection and a donation from Project Bird Watch/ Indonesian Parrot Project (PBW/IPP). R. W. R. J. Dekker, Chair of the WPA/BirdLife/ SSC Megapode Specialist Group, has been a constant source of advice, logistical support and encouragement. A. Göth and D. N. Jones readily shared unpublished information on longevity and generation length in Alectura. On Waigeo, village authorities and landowners kindly granted permission to trespass traditionally owned land, and more than 20 field collaborators contributed immensely to the results presented here.

\section{References}

Anonymous (2000) Perubahan status sebagian kawasan hutan Cagar Alam Waigeo Barat [Status change of a part of the forest area West Waigeo Nature Reserve.]. Technical Paper, BKSDA Sorong.

Anonymous (2002a) Bruijn's Brush-turkey seen. World Birdwatch 24: 5 .

Anonymous (2002b) Observations of Bruijn's Brush-turkey Aepypodius bruijnii on Waigeo, Papua. OBC Bull. 36: 40-41, 49.

BirdLife International (2001) Threatened birds of Asia: The BirdLife International Red Data Book. Cambridge, U.K.: BirdLife International.

Birks, S. M. and Edwards, S. V. (2002) A phylogeny of the megapodes (Aves: Megapodiidae) based on nuclear and mitochondrial DNA sequences. Mol. Phylogenet. Evol. 23: 408-421.

Dekker, R. W. R. J. and Argeloo, M. (1993) Bruijn's Brush-turkey Aepypodius bruijnii remains a mystery. Megapode Newsletter 7: 15-17. 
Dekker, R. W. R. J. and McGowan, J. K. (1995) Megapodes: An action plan for their conservation 1995-1999. WPA/Birdlife/SSC Megapode Specialist Group. Gland, Switzerland, Cambridge and Reading, U.K.: IUCN and World Pheasant Association.

Dekker, R. W. R. J., Fuller, R. A. and Baker, G. C., eds. (2000) Megapodes: Status survey and conservation action plan 2000-2004. WPA/Birdlife/SSC Megapode Specialist Group. Gland, Switzerland, Cambridge and Reading, U.K.: IUCN and World Pheasant Association.

De Schauensee, R. M. (1940) Rediscovery of the megapode, Aepypodius bruynii. Auk 57: 83-84.

Diamond, J. (1986) Proposed studies of conservation problems on the western Papuan islands (Raja Ampat Islands), Irian Jaya. World Wide Fund for Nature Indonesia. Unpublished report.

Heij, C. J. and Post, J. N. J. (2001) Bruijn's Brush-turkey Aepypodius bruijnii rediscovered on Waigeo. Megapode Newsletter 15: 2-5.

IUCN (2001) IUCN Red List categories and criteria. Version 3.1. IUCN Species Survival Commission. Gland, Switzerland and Cambridge, U.K.: IUCN.

IUCN (2003) Guidelines for using the IUCN Red List categories and criteria. Prepared by the Standards and Petitions Subcommittee of the IUCN SSC Red List Programme Committee. Gland, Switzerland and Cambridge, U.K.: IUCN.

Jones, D. N. (1987) Behavioural ecology of reproduction in the Australian brush-turkey Alectura lathami. PhD dissertation, Griffith University, Brisbane, Australia. RAOU Microfiche series no. 33 .

Jones, D. N. (1988a) Selection of incubation sites by the Australian Brush-turkey, Alectura lathami. Ibis 130: 251-260.

Jones, D. N. (1988b) Construction and maintenance of the incubation mounds of the Australian Brush-turkey Alectura lathami. Emu 88: 210-218.

Jones, D. N. (1990a) Male mating tactics in a promiscuous megapode: patterns of incubation mound ownership. Behav. Ecol. 1: 107-115.

Jones, D. N. (1990b) Social organisation and sexual interactions in Australian brush-turkeys (Alectura lathami): implications of promiscuity in a mound-building megapode. Ethology 84: 89-104.

Jones, D. N., Dekker, R. W. R. J. and Roselaar, C. S. (1995) The Megapodes Megapodiidae. Oxford: Oxford University Press.

Marchant, S. and Higgins, P. J., eds. (1993) Handbook of Australian, New Zealand \& Antarctic birds. Volume 2: Raptors to lapwings. Melbourne: Oxford University Press.

Mauro, I. (2002) Stop Press! 08/06/02 Bruijn's Brush-turkey Aepypodius bruijnii for the first time observed in the wild. Megapode Newsletter 16: 2-3.

Mauro, I. (2004) The field discovery, ecology, monitoring and conservation of an enigma: Bruijn's Brush-turkey Aepypodius bruijnii Oustalet 1880. Final report to Van Tienhoven Foundation for International Nature Protection and WPA/Birdlife/SSC Megapode Specialist Group, Leiden.

Mauro, I. (2005) Field discovery, mound characteristics, bare parts, vocalisations and behaviour of Bruijn's Brush-turkey Aepypodius bruijnii. Emu 105: 273-281.

Moeliker, C. W. (2002a) DB Actueel: Bruijn's Brush-turkey comes to life. Dutch Birding 24: 323-324.

Moeliker, C. W. (2002b) Bruijn's Boshoen komt tot leven. Straatgras 14: 26.

Moeliker, K. and Heij, K. (2002) Het Bruijns boshoen is binnen. Straatgras 14: 49-50.

Moeliker, C. W., Heij, C. J., Post, J. N. J. and Kompanje, E. J. O. (2003) A new, a forgotten and a lost specimen of Bruijn's Brush-turkey Aepypodius bruijnii. Megapode Newsletter 17: 2-8.

Palmer, C., Christian, K. A. and Fisher, A. (2000) Mound characteristics and behaviour of the Orange-footed Scrubfowl in the seasonal Tropics of Australia. Emu 1oo: 54-63.

Peters, J. L. (1934) Check-list of birds of the world. Volume 2. Cambridge, Mass: Harvard University Press.

Proctor, J. (2003) Vegetation and soil and plant chemistry on ultramafic rocks in the tropical Far East. Perspect. Plant Ecol. Evol. Syst. 6: 105-124. 
Sinclair, J. R. (2001) Temperature regulation in mounds of three sympatric species of megapode (Aves: Megapodiidae) in Papua New Guinea: testing the 'Seymour Model'. Aust. J. Zool. 49: 675-694.

Sinclair, J. R. (2002) Selection of incubation mound sites by three sympatric megapodes in Papua New Guinea. Condor 104: 396-406.

Stattersfield, A. J., Crosby, M. J., Long, M. J. and Wege, D. C. (1998) Endemic bird areas of the world: priorities for biodiversity conservation. Cambridge, U.K.: BirdLife International. (Conservation Series 7).

Takeuchi, W. (2003) An ecological summary of the Raja Ampat vegetation. In R. Donnelly, D. Neville and P. J. Mous, eds. Report on a rapid ecological assessment of the Raja Ampat Islands, Papua, Eastern Indonesia, held October 30 - November 22, 2002. Final Draft November 2003. Bali, Indonesia: The Nature Conservancy - Southeast Asia Center for Marine Protected Areas.

van Royen, P. (1960) Sertulum Papuanum 3. The vegetation of some parts of Waigeo Island. Nova Guinea, New Series, Bot. 10: 25-62.

\section{IWEIN MAURO}

P. O. Box 289, Sorong 98401, Indonesia. E-mail: iweinmauro@gmail.com

Received 5 November 2004; revision accepted 18 October 2005 